\title{
A new Late Antique property inscription from the Isaurian city of Germanicopolis recording a landlord by the name of Nikopssianis owner of a proastion/topothesia
}

\author{
Mehmet ALKAN*
}

The inscribed limestone block, today preserved in the museum of Karaman/Laranda, was found in 2016 during the course of road construction work at Karalar, on the outskirts of Ermenek /Germanicopolis located near the dam about $2 \mathrm{~km}$ south of the town centre ${ }^{1}$. At the site of Karalar there is also a small necropolis including some sarcophagi. The inscription is an informative document concerning agricultural production in Germanicopolis during Antiquity ${ }^{2}$.

The back face of the rectangular block is roughewn. All four sides of the block are cut straight and the traces of the patent hammer are visible as on the facade. The form and the workmanship of the stone suggest that it was probably employed in a wall.

Dimentions: H: $40 \mathrm{~cm}$; W: $61 \mathrm{~cm}$; D: $18 \mathrm{~cm}$; L. H: 2.5-6.5 cm.

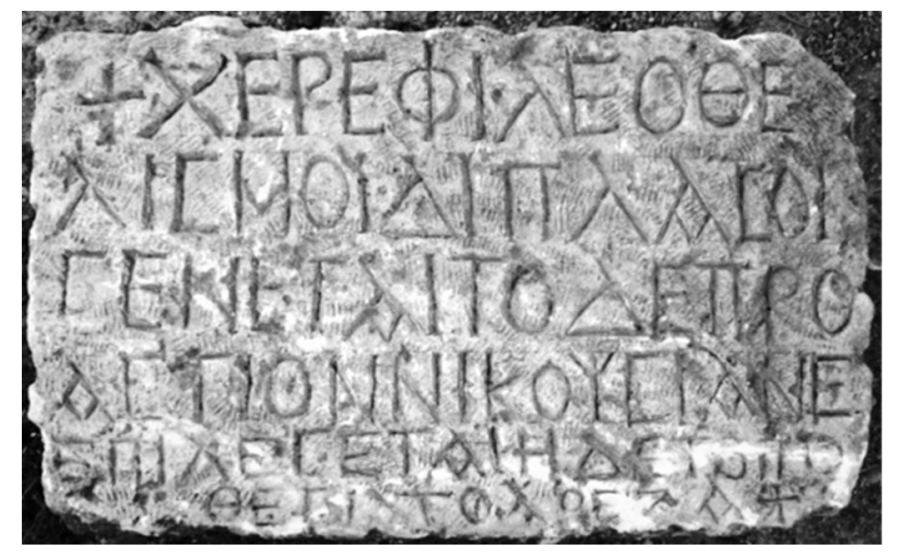

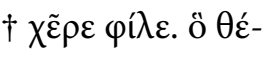

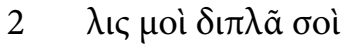

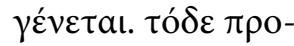

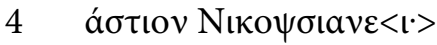

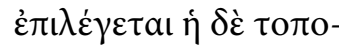

6

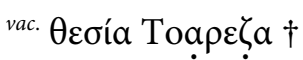

"Greeting friend. Whatever that you wish for me get twice as much to you. This (is) Nikopssianis's proastion; besides, (it) is said as the Toareza topothesia".

\section{Apparatus criticus and the type of the inscription}

L. 1-2: $\chi \tilde{\varepsilon} \rho \varepsilon=\chi \tilde{\eta} \rho \varepsilon=\chi \alpha \tilde{\rho} \rho \varepsilon . \theta \varepsilon \dot{\lambda} \backslash \varsigma=\theta \varepsilon \dot{\lambda} \lambda \varepsilon \iota$, from the verb $\theta \dot{\varepsilon} \lambda \omega$ or $\dot{\varepsilon} \theta \dot{\varepsilon} \lambda \omega$.

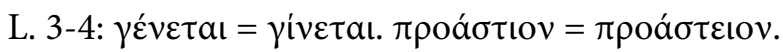

\footnotetext{
* Dr. Öğretim Üyesi Mehmet Alkan, Karamanoğlu Mehmetbey Üniversitesi, Edebiyat Fakültesi, Arkeoloji Bölümü, Yunus Emre Yerleşkesi, 70100 Karaman (mehmetalkan@kmu.edu.tr).

${ }^{1}$ I thank İlhami Etçi and Ömer Battır, local journalists in Ermenek, who informed us about the unearthing of this inscription.

${ }^{2}$ A project with the title "Agricultural production and production techniques in Ermenek and its vicinity in Antiquity" is presently being conducted by the archaeology department of Karamanoğlu Mehmetbey University and I am grateful to the project's team for the permission to publish this inscription.
} 


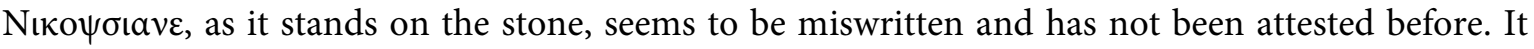
should be the proper name of a person, who owned the proastion, and it needs to be restored gramatically in the genetive or dative case. A narrow letter was probably missed out by the stone cutter, as there is no broken edge to the stone, nor is there any trace of a letter after the epsilon. Only iota would fit within the space of the vacancy at the end of the line and it seems to be the most appropriate letter.

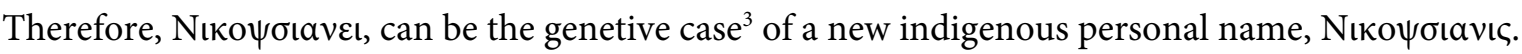

L. 6: Toape $\zeta$ : The first of the suspicious read letters may be lambda (not delta), the other can also be

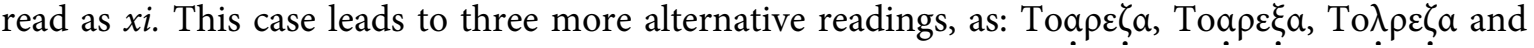

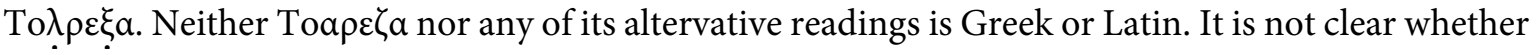

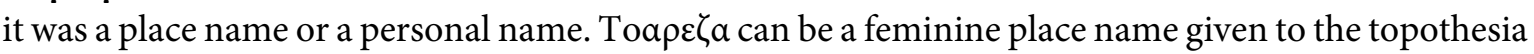
or it can be a native masculine personal name in the genitive case of the nominative Toope $\zeta \alpha$, namely an alias of Nikopssianis. In this case the last sentence can be translated as "(it) is also said as the topothesia of Toarezas". In addition, in terms of phonetics, it seems very interesting to see the simi-

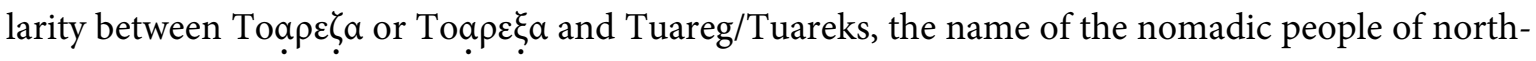
ern Africa.

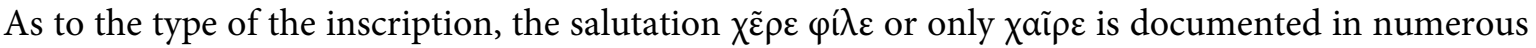
funerary inscriptions from many ancient regions. The benision sentence of ö $\theta \dot{\varepsilon} \lambda ı \varsigma$ oò $\delta ı \pi \lambda \tilde{a}$ ooì $\gamma \varepsilon$ vetaı seems as a tradition to have originated from a monotheistic religion. A very similar expres-

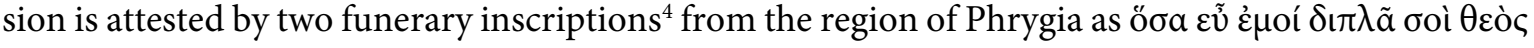

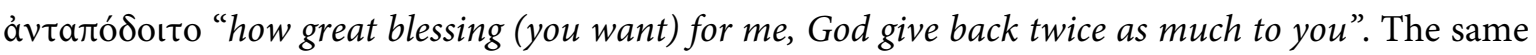
prayer is still employed in Anatolia as "hakkımda ne düşünüyorsan Allah sana iki katını versin". Although this first part of the inscription seems to have been formuled as an epitaph, this is not a funerary inscription. The terms proastion and topothesia in the second part of the inscription (1l. 3-6) are certainly recorded here not in connection with any cemetery or a tomb ${ }^{5}$. Both of these terms used with the same meaning indicate only a property in the possession of the inscribed stone's owner. The

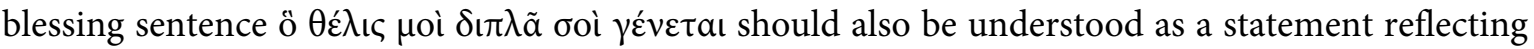
the wish of a landowner who wants to produce a high income from his property or estate. Therefore, it can be stated that this type of inscribed document was a "property inscription".

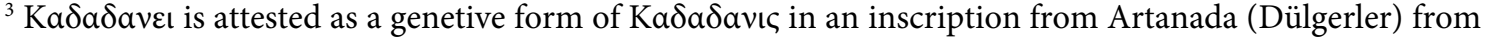
the region of Isauria, Sterrett 1888, 74-75 no. 128; Zgusta 1964, $\$ 500-13$; Brixhe 1984, 73. Another example is $\Xi \mu \varepsilon \varepsilon$, the genetive form of $\Xi \mu \mu \varsigma$ which is recorded in an inscription from Pisidia, see Alkan 2010, 42; for the critics of the inscription, see BE 125, 2012, 663-664 no. 434.

${ }^{4}$ Anderson 1889, 306-307 no. 246; MAMA VII, 260. Both of these inscriptions were found within the modern village of Piribeyli in the province of Konya (Iconion).

${ }^{5}$ The term proastion together with necropolis is only found in Strabo's account of Alexandria in Egypt. Strabon records a proastion necropolis, namely "the necropolis outside of the city" of Alexandreia, Strab. XVII.1.

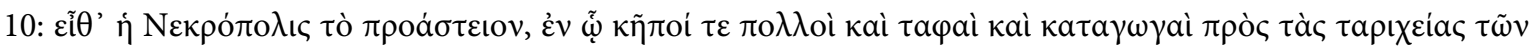
$\nu \varepsilon \kappa \rho \tilde{\omega} v \dot{\varepsilon} \pi \iota \tau \dot{\delta} \delta \varepsilon \iota \alpha$. We find the term of topothesia in a funerary inscription from the city of Nicaia in Bithynia,

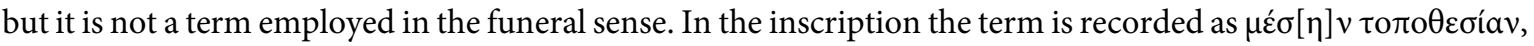

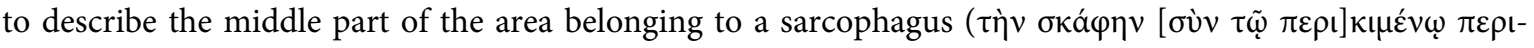
[ $\beta$ ó $\lambda \omega]]$ ), for this inscription see INikaia 117.
} 


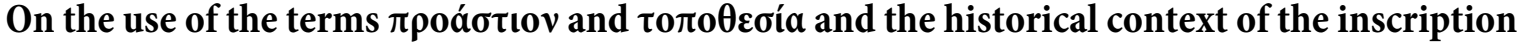

As can be understood from the syntax of the second part of the inscription and from the verb $\dot{\varepsilon} \pi \imath \lambda \dot{\varepsilon} \gamma \omega$, proastion and topothesia are used as two different terms referring to the same object, the property of Nikopssianis. At first glance it seems difficult to understand why the people of Germanicopolis called this property both proastion and topothesia. The understanding of the use of these terms depends upon the documents in which the terms proastion and topothesia are mentioned. Most of the evidence concerning these terms are in the texts on papyrus found in Egyptian cities, especially those dating from the Early Byzantine Period.

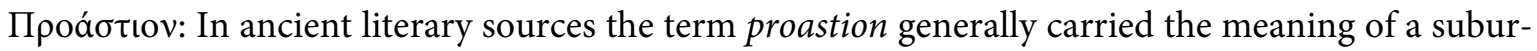
ban or military settlement outside of a city gate ${ }^{6}$. Rather than its classical sense in the literary sources of suburban, the epigraphic documents from Late Antiquity, including those on papyrus attest that the term proastion, as well as meaning a settlement, was also used to describe a large estate or the maison of a proprietor's field outside a city ${ }^{7}$.

In a text on papyrus from the Egyptian city of Arsinoites concerning a rental agreement ${ }^{8}$, which is dated to the middle of sixth century A.D., the term proastion was used as (1l. 5-8):

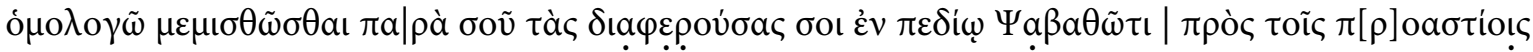

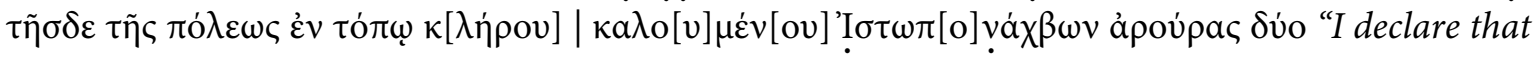
I have hired from you two arurai in the properties belonging to you, in the topos of the kleros called Istoponachbon in the Psabathos plain in front of the proastia of the city ...". The word aroura in this text is employed as a measure of land. It is possible to understand from the text that the proastia were the urban settlements outside the city.

In another text again from the city of Arsinoites on papyrus ${ }^{9}$, dated to between 222 and 235 A.D., indicates that proastia, in the plural case, were the fields belonging to a village. The relevant lines of the text, which is the petition of a libelland asking for a clarification about his donkey found dead, are as follows:

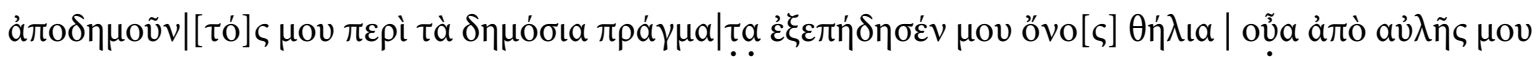

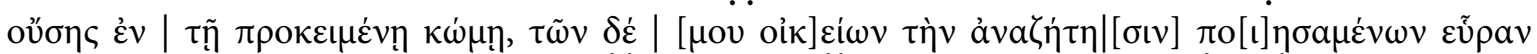

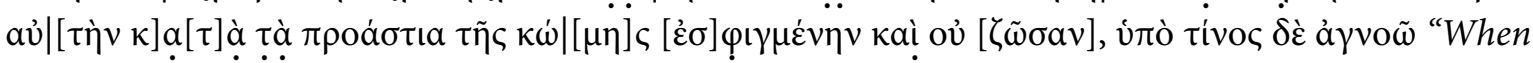
I was from home for the public affairs, my donkey leaped out my courtyard being in the prescribed village (Teptynis), then my familiars, by investigation throughout the proastia of the village, found it exhaused; I am ignorant of this".

The term proastion also indicates a property of a private person, as in, $\pi \rho 0 \alpha \sigma \tau i(\mathrm{ov})$ 'Po $\pi \lambda u \varepsilon i v o v$ recorded in line 16 of a text on papyrus dating from the $6^{\text {th }}-7^{\text {th }}$ centuries found in the city of Aphroditopolis which includes a list of various services ${ }^{10}$.

\footnotetext{
${ }^{6}$ Husson 1967, 187; Audring 1981; Schuler 1998, 105-107.

${ }^{7}$ Rouillard 1953, 88-89; Husson 1967, 192-193; Goodman 2007, 27-28.

${ }^{8}$ DDbDP transcription: sb.18.13885.

${ }^{9}$ DDbDP transcription: sb.6.9203.

${ }^{10}$ DDbDP transcription: sb.20.14705.
} 
It can be seen from the text recorded on another papyrus ${ }^{11}$ dated 584 A.D., a payment receipt found in the archive of the famous estate of the Apiones family in the city of Oxyrhynchus, that the proastion was a manor house or a bath house:

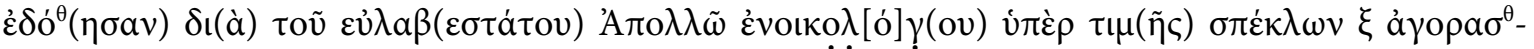

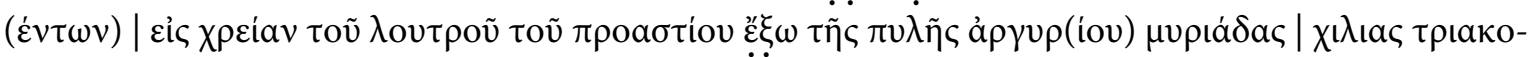

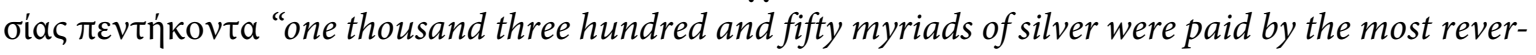
ent rent-collector Apollo for the price of 60 windows bought for the need of the proastion outside of the city". These 60 windows probably belonged a mansion or to a large estate bathhouse ${ }^{12}$ used by the slaves and/or the labourers who worked the estate.

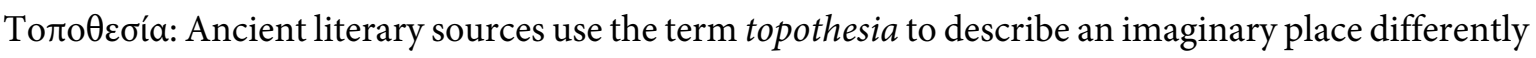
from the topography ${ }^{13}$ describing a particular place as a country, city, land etc. Despite this, some epigraphic and papyrological documents from Egypt dating from Late Antiquity indicate that the term topothesia was used to specify a certain place as a district, land or landed property.

A papyrus text ${ }^{14}$ dated to 632 A.D., which includes a contract concerning the tenancy of an agricultural land belonging to a church, records the term topothesia in the part between the lines 9 and 15

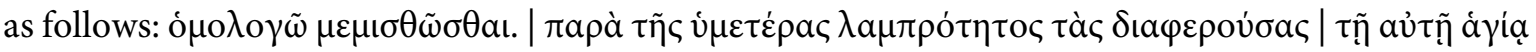

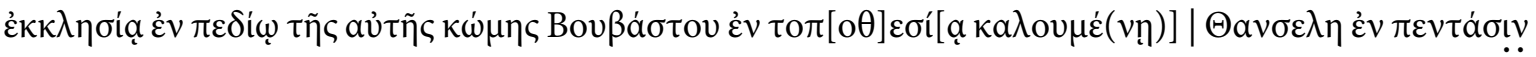

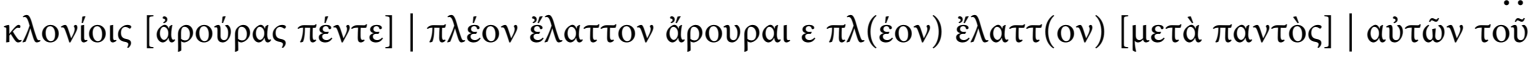
$\delta$ เкaíov. In this evidence, the topothesia called Thansele seems to be a large district including the Boubastos village with its plain (pedion) in which there were agricultural lands and an ekklesia.

In a land leasing agreement recorded on a papyrus text ${ }^{15}$ from the city of Arsinoite dated 543 A.D., topothesia is seen as a district, in a plain where there were some pieces of land. The relevant lines of the text are (1l. 6-10):

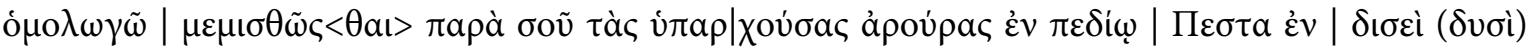

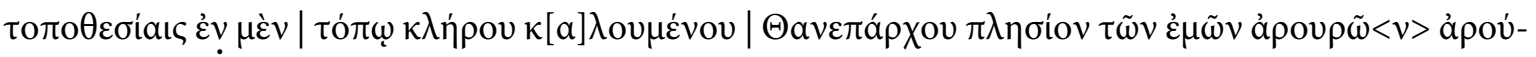

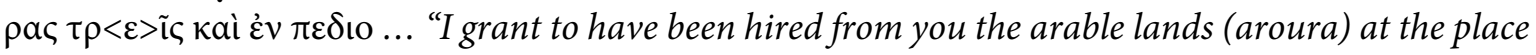
(topos) of the farmland (cleros) called Thaneparchos, near to our lands, in two topothesia in the Pesta plain (pedion).

In another text on papyrus $^{16}$ found in the Egyptian city of Aphroditopolis and dated to 514 A.D., topothesia appears also a large rental farmland, called Pchetos topothesia, 11. 6-10:

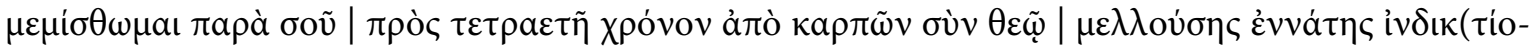

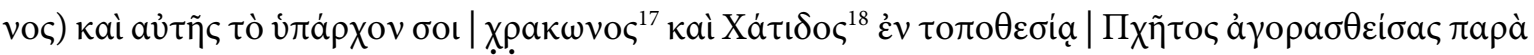

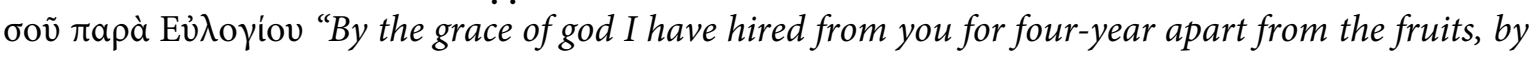

\footnotetext{
${ }^{11}$ DDbDP transcription: p.wisc.2.66.

${ }^{12}$ Husson 1967, 194.

${ }^{13}$ Ziegler 1937, 1722-1723 s.v. Topographia.

${ }^{14}$ DDbDP transcription: sb.6.9461.

${ }^{15}$ DDbDP transcription: stud.pal.20.142.

${ }^{16}$ DDbDP transcription: p.flor.3.279.

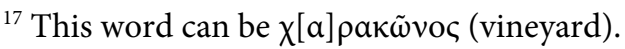

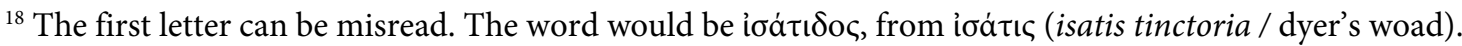


making a convenant to begin from the nineth indictio, your property with the vineyard and isatis in the Pchetos topothesia, which you bought from Eulogios".

In the folloving passage quoted from a papyrus text ${ }^{19}$, from Hermoupolis and dated 476 A.D., including a land leasing agreement, topothesia can be understood as a term employed to describe cultivated land, land that could be subdivided into agricultural parsels:

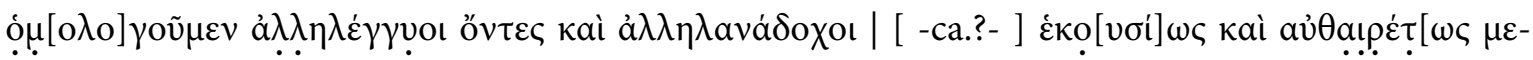

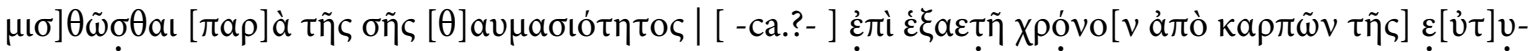

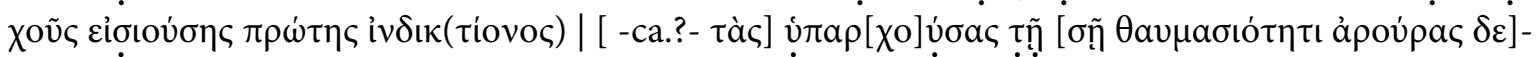

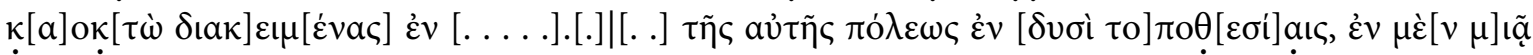

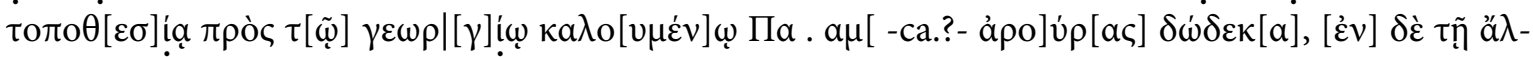

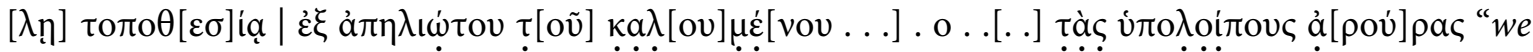
mutual sureties and giving mutual security agree voluntary and independently that the properties of eighteen arourai being in your possession in [---] to have been leased from you venerable as free from fruits for six years from the beginning of the first indictio. [---] of the same city in two topothesiai, twelve arourai in one topothesia near the cultivated area (georgion) called Pa[.] am [---], the remaining arourai in the other topothesia on the east wind of [---] called [---]".

Topothesia is also employed to describe farmland in another text on papyrus from the city of Oxyrhynchos, dated 179 A.D..$^{20}$, concerning the sale of a farm; 11. 7-8:

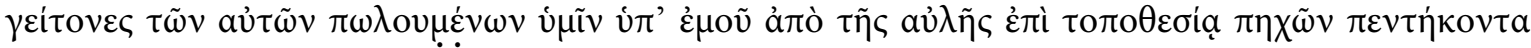

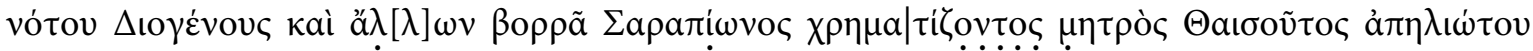

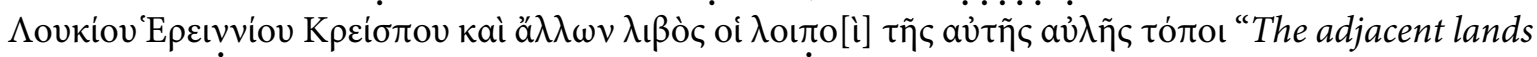
sold to you by me, from the court on the topothesia (are) fifthy cubits southward of that of Diogenes and others, on the north that of Sarapion called as the son of the mother Thaisous, on the east that of Lucius Herennios Crispus and others, on the west the remaining places of the same court".

In a correspondence between Alypoios and Heroneinos documented through another papyrus ${ }^{21}$ from the Egyptian city of Theadelphia and dated 266-7 A.D., the term topothesia can be understood as indicating a portion of cultivated land, which was under the responsiblity of a house-steward. The relevant sentence of the text, between the lines 10 and 15 , is as follows:

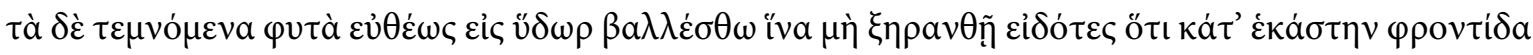

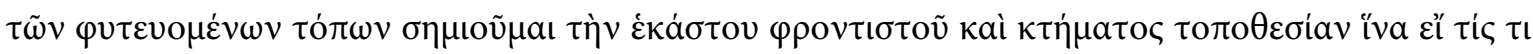

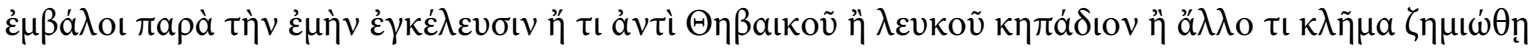

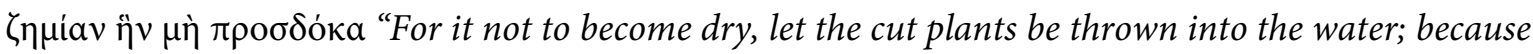
each portion of the cultivated land I marked as the topothesia each of the procurator and of the property, that anyone does not make any attack against my command or against white vineyard of Thebaikos or against the vines or another any criminal offence which I have not expected".

\footnotetext{
${ }^{19}$ DDbDP transcription: bgu.12.2151.

${ }^{20}$ DDbDP transcription: sb.20.14199.

${ }^{21}$ DDbDP transcription: p.flor.2.148.
} 


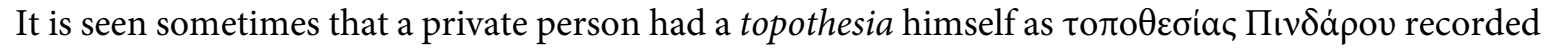
in a text on papyrus ${ }^{22}$ from the Egyptian city of Antinoopolis dated to 568 A.D.

An inscription ${ }^{23}$ found near the Delta in Egypt, dating from Late Antiquity or the Early Christian period, records a topothesia called Boukola that belonged to the oúoia (ousia) of a certain Menas. The Boukola topothesia was probably an area of farmland in the possession of Menas. The word ousia ${ }^{24}$ can be understood as describing an estate in the most general sense.

It is consequently clear that both terms proastion and topothesia were used to indicate the real estates of Nikopssianis. The possession of Nikopssianis must have been an estate comprising two properties, one of which corresponded to one of the meanings of proastion, the other corresponded to the meaning conveyed by the term topothesia. As can be concluded from the evidence given above on the use of both terms, proastion was a residence and topothesia was an area of cultivated land. This seems the most meaningful interpretation in accordance with the context provided by this inscription. Namely, the proastion of Nikopssianis or in other words the Toareza topothesia must have been his farmstead, which comprised of a mansion and some arable land. The people of Germanicopolis probably used both terms proastion and topothesia, to correspond to an estate or farmstead with a residence and a cultivated land in a single sense.

This farmstead or estate of Nikopssianis in the suburb of Germanicopolis was managed by himself or those who worked under of him as slaves or labourers. The landowner Nikopssianis was probably producting wine $\mathrm{e}^{25}$ on his estate. It can not be considered that the property of Nikopssianis formed a large estate, like those in Egypt where there were most poweful families holding very large estates. One of them was the rich and famous Apion family, which is well known through the papyri from the archive found at the city of Oxyrhynchos, and some members of this family held high offices like the consulship in the administration of the Byzantine Empire. The estate of Nikopssianis was possible an agricultural enterprise composed of a farmland with a residence, some workshops and maybe some threshing floor.

During Late Antiquity and later, many landowners like Nikopssianis would have been cultivating the lands in the suburb settlements of Germanicopolis. There are today many small rural settlements dispersed throughout the large area of cultivated land extending from the south of the city to the Calycadnus valley. In the $17^{\text {th }}$ century, the famous Ottoman traveler Evliya Çelebi visited Ermenek and in his Seyahatnâme (travel book) he described the vineyards and orchards of the town as "varoş1 bâğ-1 irem" in old Turkish (the garden of eden of the suburb). He also records that there were 12 districts each with one small mosque and 800 masonry constructions within the suburb of Ermenek ${ }^{26}$.

${ }^{22}$ DDbDP transcription: p.cair.masp.2.67162.

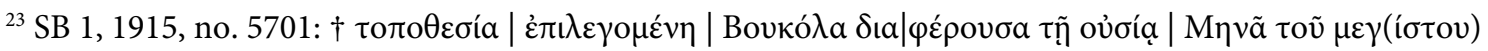

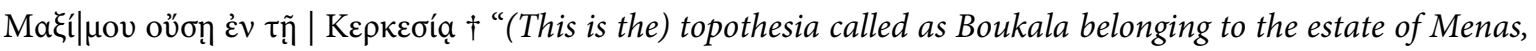
son of the great Maximus, being in the Kerkesia (village)".

${ }^{24}$ For usage of the word ousia in the meaning of the emperor's estate in the Egyptian documents, see Thompson 1987, 558; for more detail about this word, see Tacoma 2015.

${ }^{25}$ In the gardens of Ermenek there are more than 100 wine workshops. These workshops were found during the course of the surveys conducted by the department of archaeology at the university of Karamanoğlu Mehmetbey, see Aşkın 2016, 103; Aşkın et all. 2017, 179.

${ }^{26}$ Evliya Çelebi, Kitap 9, cilt 1, p. 328-330. 
Germanicopolis seems to have been a rich city in terms of its agricultural production in Late Antiquity. Politically, this wealth made it an important place amongst Isaurian cities. According to the account provided by the Roman historian Ammianus Marcellinus ${ }^{27}$, the notable men of Germanicopolis seem to have taken the role of mediators between the Isaurian bandits who rebelled in 368 A.D. and the Roman troops brought in to suppress them. Some of these notable men, who were influential persons in the government of the city, may have been landowners, who were probably employing some native Isaurian "strong-arm men" to provide security for their estates. These landowners not only served as mediators between the rebels and the Roman troops, but in this way may also have limited the number of strong-arm men willing and able to join in any rebellion ${ }^{28}$.

\section{Bibliography}

Alkan 2010

Amm. Marc.

Anderson 1889

AST

Așkın 2016

Așkın et all. 2017

Audring 1981

$\mathrm{BE}$

Brixhe 1984

DDbDP

Evliya Çelebi

Goodman 2007

Hopwood 1999
M. Alkan, A New Inscription from Pisidia, Gephyra 7, 2010, 41-45.

J. C. Rolfe (ed.), Ammianus Mercellinus, vol. III, with an English Translation (Loeb Classical Library), London $1986^{5}$.

J. G. C. Anderson, Exploration in Galatia cis Halym. II, JHS 19, 1889, 280-318.

Araştırma Sonuçları Toplantısı

E. Aşkın, Karaman İli ve Mersin İli Mut İlçesi Antik Dönem Yerleşimleri ve Yerleşim Düzenlemesi Arkeolojik Yüzey Araştırması 2014 Yılı Çalışmaları (11-15 Mayıs 2015), in: AST 33/2, Ankara 2016, 101-114.

E. Aşkın - M. Kurt - M. Alkan - H. Körsulu - H. E. Ergürer, Karaman İli ve Mersin İli Mut İlçesi Antik Dönem Yerleşimleri ve Yerleşim Düzenlemesi Arkeolojik Yüzey Araştırması 2015 Yılı Çalışmalar1 (23-27 Mayıs 2016), in: AST 34/2, Edirne 2017, 175-188.

G. Audring, Proastion: Zur Funktion der stadtnahen Landzone archaischer Poleis, Klio 63/1, 1981, 215-231.

Bulletin épigraphique

C. Brixhe, Essai sur le grec anatolien au début de notre ère, Nancy 1984.

The Duke Databank of Documentary Papyri (an electronic corpus of papyrus: http://www.papyri.info/docs/ddbdp).

S. A. Kahraman, Günümüz Türkçesiyle Evliyâ Çelebi Seyahatnâmesi, 9. Kitap, 1. Cilt, İstanbul 2010.

P. J. Goodman, The Roman City and its Periphery: from Rome to Gaul, London-New York 2007.

K. Hopwood, Ammianus Marcellinus on Isauria, in: J. W. Drijvers -

D. Hunt (eds.), The late Roman World and its Historian. Interpreting Ammianus Marcellinus, London 1999, 198-213.

\footnotetext{
${ }^{27}$ Amm. Marc., 27.9.7; Rougé 1966, 300; Matthews 1989, 364-365.

${ }^{28}$ Hopwood 1999, 205.
} 
Husson 1967

INikaia

MAMA

Matthews 1989

REA

Rouillard 1953

Rougé 1966

SB

Schuler 1998

Sterrett 1888

Strab.

Tacoma 2015

Thompson 1987

Ziegler 1937

Zgusta 1964

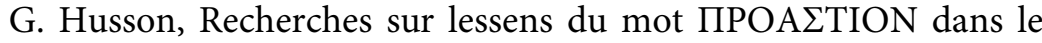
grec d'Égypte, Recherches de Papyrologie IV, 1967, 187-200.

S. Şahin, Katalog der antiken Inschriften des Museums von Iznik (Nikaia)/İznik Müzesi Antik Yazıtlar Kataloğu, Teil/Kısım 1 (IK 9), Bonn 1979.

Monumenta Asiae Minoris Antiquae

J. Matthews, The Romans Empire of Ammianus with a new introduction, London 1989.

Revue des Études Anciennes

G. Rouillard, La vie rurale dans l'Empire byzantin, Paris 1953.

J. Rougé, L'Histoire Auguste et l'Isaurie au IV ${ }^{\mathrm{e}}$ Siècle, REA LXVIII, nos. 3-4, Bordeaux 1966, 282-315.

F. Preisigke (ed.), Sammelbuch griechischer Urkunden aus Ägypten, vol. 1, Strassburg 1915.

Ch. Schuler, Ländliche Siedlungen und Gemeinden im hellenistischen und römischen Kleinasien (Vestigia 50), München 1998.

J. R. S. Sterrett, The Wolfe Expedition to Asia Minor. Papers of the American School at Athens III, Boston 1888.

A. Meineke (ed.), Geographica, Leipzig-Teubner 1877.

L. E. Tacoma, Imperial wealth in Roman Egypt: The Julio-Claudian ousiai, in: P. Erdcam - K. Verboven - A. Zuiderhoek (eds.), Ownership and Exploitation of Land and Natural Resources in the Roman World (Oxford Studies on the Roman Economy), Oxford 2015, 7187.

D. J. Thompson, Imperial Estates, in: J. Wacher (ed.), The Roman World, Vol. II, London-New York 1987, 555-567.

K. Ziegler, Topographia, RE 12, VI A.2, 1937, 1722-1723.

L. Zgusta, Kleinasiatische Personennamen, Prag 1964.

\section{Isauria kenti Germanikopolis'den yeni bir Geç Antikçağ mülkiyet yazıtı ve proastion/topothesia sahibi Nikopssianis adında bir feodal bey \\ Özet}

Feodal sistemin ortaya çıkmasına neden olan, arazi sahibi zenginler tarafından sahip olunan büyük çiftlikler Geç Antikçağ’’n ekonomik yapısında önemli bir yer almıştır. Genellikle kentlerde ikamet eden bu toprak ağaları kentlerin varoş bölgelerinde malikânelere ve tarım alanlarına sahiptiler. $\mathrm{Bu}$ feodal beyler sadece toprak zengini seçkinler değil, aynı zamanda Geç Antikçağ Dönemi yönetiminde de etkin kişilerdi.

Bu makale, Germanikopolis/Ermenek kentinden Nikopssianis adında Hıristian bir toprak ağasının kentin varoş semtindeki mülkiyetini gösteren yeni bir epigrafik belgeyi tanıtmaktadır. Yazıtın çevirisi: 
"Selam ey dost! Benim için istediğin şey sana iki katı olsun. Bu proastion Nikopssianis'in(dir); ayrıca Toareza topothesia diye de söylenir".

İlk olarak bu yazıtta birlikte görünen proastion ve topothesia terimleri Nikopssianis'in mülkiyeti olarak aynı anlamda kullanılmaktadır. Geç Antikçağ’ $1 n$ papirus ve epigrafik belgeleri, antik edebi kaynaklarda kent kapıları dışındaki varoş yerleşimi ve askeri yerleşim yeri olarak kullanılan proastion teriminin Geç Antikçağ’ da geniş çiftlik ve malikâne anlamında da kullanıldığını ortaya koymaktadır. Aynı şekilde, edebi kaynaklarda gerçekte var olmayan hayali bir yerin tasviri için kullanılan topothesia sözcügünün, Geç Antikçağ yazıtlarında ve papiruslarında bölge, mahalle, semt ve geniş tarımsal arazileri tanımlamak için kullanıldığı görülmektedir.

Sonuç itibariyle, Ermenek yazıtında aynı anlamda görülen proastion ve topothesia terimlerinin, Germanikopolis kentinin bir kenar mahallesinde Nikopssianis isimli zengin bir yurttaşın çiftliğini, yani konutuyla birlikte tarım arazisini göstermek için kullanıldığı anlaşılmaktadır.

Anahtar Sözcükler: Ermenek, Nikopssianis, proastion/proasteion, topothesia, malikâne, çiftlik, feodal bey.

\section{A new Late Antique property inscription from the Isaurian city of Germanicopolis recording a landlord by the name of Nikopssianis owner of a proastion/topothesia}

\section{Abstract}

The large estates owned by the landlords, who caused the emergence of the feudal system, had a significant place within the economic structure of Late Antiquity. These landowners were generally city dwellers possessing residences and cultivated estates outside the cities. These landowners were not only wealthy, members of the agrarian elites, but were also influential persons for the administration in Late Antiquity.

This contribution introduces a new epigraphic document indicating the property (proastion/topothesia) of a certain landlord Nikopssianis who was a Christian from the city of Germanicopolis. Both terms proastion and topothesia, which are for the first time seen together in this inscription, were used with the same meaning for the real estates of Nikopssianis. The papyrical and the epigraphic documents from Late Antiquity attest that the term proastion was also used to describe a large estate or an estate house outside of a city with the difference of its classical sense of suburban or a military settlement in the ancient literary sources. Likewise, the term topothesia, which is used in the meaning of an imaginary place in the literary sources, seems in Late Antiquity to be a word describing a certain district or a large area of agricultural land.

Consequently, with the use of the terms proastion and topothesia in this inscription it is suggested that both terms should be understood as indicating Nikopssianis's farmstead comprising both a resi dence and an area of agricultural land in the suburb of Germanicopolis.

Keywords: Germanicopolis, Nikopssianis, proastion/proasteion, topothesia, estate, landlord. 